\title{
Correlation Between Brain-Derived Neurotrophic Factor Levels and Serum Iron Levels in Stunted Children Living in Malaria-Endemic Areas
}

Rostika Flora ${ }^{1 *}$, Mohammad Zulkarnain², Nur Alam Fajar ${ }^{1}$, Achmad Fickry Faisa ${ }^{3}$, Nurlaily Nurlaily ${ }^{4}$, Ikhsan Ikhsan ${ }^{4}$, Samwilson Slamet ${ }^{4}$, Risnawati Tanjung ${ }^{5}$

${ }^{1}$ Public Health Science Study Program, Faculty of Public Health, Sriwijaya University, Palembang, Indonesia; ${ }^{2}$ Public Health Science, Faculty of Medicine, Sriwijaya University, Palembang, Indonesia; ${ }^{3}$ Environmental Health Science Study Program, Faculty of Public Health, Sriwijaya University, Palembang, Indonesia; ${ }^{4} D-I I I$ in Nursing Study Program, Faculty of Mathematics and Natural Sciences, Bengkulu University, Bengkulu, Indonesia; ${ }^{5}$ Environmental Health Study Program, Health Polytechnic of Medan, Indonesia

Edited by: Ksenija Bogoeva-Kostovska Nurlaily N, lkhsan I, Slamet S, Tanjung R. Correlation Setween Brain-Derived Neurotrophic Factor Levels and Endemic Areas. Open Access Maced J Med Sci. 2020 May $10 ; 8(\mathrm{E}): 318-321$ https://doi.org/10.3889/oamjms. 2020.4090 Keywords: Elementary schoolchildren; Stunting; Serum iron; Brain-derived neurotrophic factor Correspondence: Rostika Flora, Public Health Science Study Program, Faculty of Public Health, Sriwijaya University, Palembang, Indonesia mail: rostikaflora@gmail.com Revised: 23-Jan-2020 Revised: 23-Jan-2020
Accepted: 07-Mar-2020
Copyright: $\odot 2020$ Rostika Flora, Mohammad Zulkarnain, Nur Alam Fajar, Achmad Fickry Faisa, Nurlaily Nurlaily, Ikhsan Ikhsan, Samwilson Slamet, Risnawati Tanjung
Funding: This research did not receive any financial Funding: This research did not receive any financia
support Competing Interests: The authors have declared that no competing interests exist Open Access: This is an open-access article distribute under the terms of the Crealive Commons Attribution-

\begin{abstract}
BACKGROUND: Children who are living in malaria-endemic areas are highly vulnerable to malaria infections. The presence of malaria infection and low nutrient intake results in an increased incidence of stunting in children especially those living in malaria-endemic areas. The stunting in children may reduce their cognitive functions.

AIM: This study aims to analyze the correlation between brain-derived neurotrophic factor (BDNF) levels and serum iron in stunted children living in malaria-endemic areas.

METHODS: The design of this research was a case-control study. The sample of this study was 60 elementary schoolchildren aged 9-12 years collected from five regencies in Bengkulu province. Among the samples, 30 of them were stunted and the remaining were non-stunted ones. The technique used to collect the samples was simple random sampling. Growth stunting was identified by calculating the Z-score of height-for-age (H/A). In addition, the whole blood of each research subject was drawn for the measurement of BDNF and serum iron levels. Serum BDNF level was measured using a method of enzyme-linked immunosorbent assay (ELISA), and serum iron level was measured using spectrophotometry. The characteristic data of the sample were collected from questionnaires. The obtained research data were then analyzed using the independent t-test and the Pearson correlation.

RESULTS: The levels of BDNF and serum iron in stunted children were lower than those in non-stunted ones (3.38 \pm 1.05 vs. $4.16 \pm 0.41 \mu \mathrm{g} / \mathrm{dL}$ and $31.57 \pm 9.88$ vs. $52.99 \pm 12.60 \mu \mathrm{g} / \mathrm{dL})$. There was a significant difference $(p<0.05)$ in the mean level of BDNF and serum iron levels between stunted children and non-stunted ones. The results of the Pearson analysis on BDNF and serum iron levels indicated $p=0.000$ and $r=0.454$
\end{abstract}

CONCLUSION: There was a significant correlation between BDNF levels and serum iron levels in stunted children living in malaria-endemic areas.

\section{Background}

Malaria infection is one of the most contributing factors to the high rate of morbidity and mortality. Most of the areas in Indonesia are still endemic for malaria infection [1]. Children living in malaria-endemic areas are vulnerable to develop malaria infection. Seluma regency is one of the areas in Indonesia, which is endemic for malaria. Not only marked as one of the malaria-endemic areas but Seluma regency is also considered as an underdeveloped regency [2]. The presence of malaria infection and the lower intake of nutrition increases the incidence of growth stunting in children living in malaria-endemic areas.

Stunting is resulting from chronic undernutrition, and it is believed that stunting is triggered by poor dietary intake, infectious diseases, and environmental problems [3]. The results of a similar study conducted by Pongou et al. and Ramli et al. stated that family socioeconomic, i.e., education, employment, and family income was the risk factors for stunting in children [4], [5]. Another similar study by Zere and Mc Indyre conducted in South Africa also proved that growth stunting was found higher in people with lower socioeconomic status [6]. Lower nutrient intake will lead to the lack of micronutrients needed by our bodies. One of the micronutrients closely associated with stunting is iron.

Iron is an essential nutrient not only for normal growth, health, and survival of children but also for their mental and motor development, and cognitive functioning [7]. Studies in animals proposed that iron deficiency causes epigenetic changes that change the structure of chromatin and the expression of BDNF genes. Iron deficiency lowers BDNF function and impairs 
neuronal differentiation in the hippocampus. BDNF is a neurotrophin that is required for the development of synapses, synapse plasticity, and cognitive functions. The synthesis of BDNF requires some enzymes that depend on iron availability to work [8]. This study was to analyze the correlation between serum iron and BDNF levels in stunted children living in malaria-endemic areas.

\section{Methods}

This study was conducted in malaria-endemic areas in Seluma regency, Bengkulu province. The design of this study was a case-control study design that compared two groups of elementary schoolchildren, the first group was stunted and the second one was nonstunted. The study was conducted, in April 2019, involving a sample of 60 elementary schoolchildren taken by simple random sampling. The children came from elementary schools in five subdistricts, namely, Lubuk Sandi, Seluma Barat, Seluma Timur, Seluma Utara, and Talo. The growth stunting was determined by comparing the actual height values with the appropriate age. The Z-score was calculated by referring to anthropometric data of children and the WHO global database in terms of child growth and malnutrition using Anthro 1.02 software. The children who had a Z-score below or lower than -2 were determined as stunted [9]. After calculating and determining the children's status in stunting, $2 \mathrm{~mL}$ venous blood was taken from the children to measure the levels of serum iron and BDNF. The determination of serum iron levels was performed by spectrophotometric methods using the Iron Liq kit (Cat. No. 10230, human diagnostic), and that of BDNF levels by the enzyme-linked immunosorbent assay (ELISA) method using Human BDNF ELISA KIT (Cat. No. E-EL H0010, Elabsience). Then, all the data were computably analyzed using SPSS version 20 with the Chi-square and Pearson tests $(p<0.05)$. This study had received its ethical approval numbered 46/UN9.1.10/ KKE/2019 from the Health Research Ethics Commission, Faculty of Public Health, Sriwijaya University.

\section{Results}

The results of this present study (Table 1) showed that $72.7 \%$ of the children aged $>10-12$ years old were stunted, and $59.3 \%$ of the female students were stunted. Based on parental characteristic data, $60 \%$ of the mothers with low education background had stunted children, and $55.9 \%$ of those who did not work had stunted children.

Likewise, father's characteristic data showed that fathers with low education had stunted children,
Table 1: Frequency distribution of elementary school students' characteristics

\begin{tabular}{|c|c|c|c|c|c|c|}
\hline \multirow[t]{2}{*}{ Frequency distribution } & \multicolumn{2}{|c|}{ Stunted } & \multicolumn{2}{|c|}{ Non-stunted } & \multicolumn{2}{|c|}{ Total } \\
\hline & $\mathrm{n}$ & $f(\%)$ & $\mathrm{N}$ & $f(\%)$ & $\mathrm{n}$ & $f(\%)$ \\
\hline \multicolumn{7}{|l|}{ 1. Age } \\
\hline a. 9-10 years old & 14 & 36.8 & 24 & 63.2 & 38 & 100 \\
\hline b. $>10-12$ years old & 16 & 72.7 & 6 & 27.3 & 22 & 100 \\
\hline \multicolumn{7}{|l|}{ 2. Sex } \\
\hline a. Male & 16 & 59.3 & 11 & 40.7 & 27 & 100 \\
\hline b. Female & 14 & 42.4 & 19 & 57.6 & 33 & 100 \\
\hline \multicolumn{7}{|l|}{ 3. Malaria infection } \\
\hline a. Positive & 0 & 0 & 0 & 0 & 0 & 0 \\
\hline b. Negative & 30 & 50.0 & 30 & 50.0 & 60 & 100 \\
\hline \multicolumn{7}{|l|}{ 4. Mother's education } \\
\hline a. Low & 24 & 60.0 & 16 & 40.0 & 40 & 100 \\
\hline b. High & 6 & 30.0 & 14 & 70.0 & 20 & 100 \\
\hline \multicolumn{7}{|l|}{ 5. Mother's occupation } \\
\hline a. Worker & 11 & 42.3 & 15 & 57.7 & 26 & 100 \\
\hline b. Housewife & 19 & 55.9 & 15 & 44.1 & 34 & 100 \\
\hline \multicolumn{7}{|l|}{ 6. Father's education } \\
\hline a. Low & 20 & 54.1 & 17 & 45.9 & 37 & 100 \\
\hline b. High & 10 & 43.5 & 13 & 56.5 & 23 & 100 \\
\hline \multicolumn{7}{|l|}{ 7. Father's occupation } \\
\hline a. Civil servant & 2 & 40.0 & 3 & 60.0 & 5 & 100 \\
\hline b. Worker in the private sector & 27 & 49.1 & 28 & 50.9 & 55 & 100 \\
\hline \multicolumn{7}{|l|}{ 8. Economic status } \\
\hline a. Low & 26 & 59.9 & 18 & 40.1 & 44 & 100 \\
\hline b. High & 4 & 25.0 & 12 & 75.0 & 16 & 100 \\
\hline
\end{tabular}

and $49.1 \%$ of those who worked in the private sector had stunted children. Based on economic status, $59.9 \%$ of the families with low economic status had stunted children. The results of laboratory examination for BDNF levels (Table 2) showed that the mean level of BDNF of stunted children was lower than that of non-stunted ones ( $3.38 \pm 1.05$ vs. $4.16 \pm 0.41 \mu \mathrm{g} / \mathrm{dL})$.

Table 2: Comparison of BDNF mean levels between stunted and non-stunted children

\begin{tabular}{llll}
\hline Status of H/A & \multicolumn{3}{c}{ BDNF Levels } \\
\hline & $\mathrm{N}$ & Mean $\pm \mathrm{SD}(\mu \mathrm{g} / \mathrm{dL})$ & $\mathrm{p}$ \\
\hline Stunted & 30 & $3.38 \pm 1.05$ & 0.001 \\
Non-stunted & 30 & $4.16 \pm 0.41$ & \\
\hline
\end{tabular}

Similarly, the results of the examination of serum iron levels (Table 3 ) found that the mean serum iron levels in stunted children were lower than that of non-stunted ones $(31.57 \pm 9.88$ vs. $52.99 \pm 12.60 \mu \mathrm{g} / \mathrm{dL})$.

Table 3: Comparison of serum iron levels between stunted and non-stunted children

\begin{tabular}{llll}
\hline Status of H/A & \multicolumn{3}{c}{ Iron Levels } \\
\hline & $\mathrm{N}$ & Mean $\pm \mathrm{SD}(\mu \mathrm{g} / \mathrm{dL})$ & $\mathrm{P}$ \\
\hline Stunted & 30 & $31.57 \pm 9.88$ & 0.000 \\
Non-stunted & 30 & $52.99 \pm 12.60$ & \\
\hline
\end{tabular}

The results of the correlation test (Graph 1) between BDNF levels and serum iron levels showed that there was a significant correlation $(p=0.0000)$

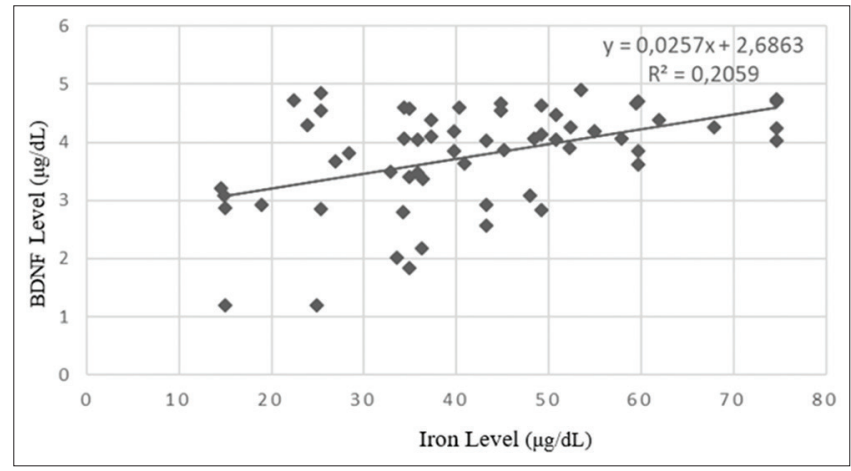

Graph 1: Correlation between BDNF serum levels and serum iron levels $(r=0.454, n=60, p$-value $=0.000)$ 
between serum BDNF levels and serum iron levels with coefficient correlation in a moderate level $(r=0.454)$.

\section{Discussion}

Based on the data characteristics, $72.7 \%$ of the stunted children were in the age of > 10-12 years old, and $59.3 \%$ of them were male. According to Akombi et al., stunting in infants is often not realized by parents, and it is more visible when they are growing older. In terms of gender, male students are said to have a higher risk of the developing stunting compared to girls. This is because in general male students are physically more active than girls and consuming more energy stores in their bodies [10]. From the examination of peripheral blood smear for plasmodium, none of the children $(0 \%)$ was infected with malaria. Besides, clinical symptoms associated with malaria were not present in all research subjects. It can be assumed from these findings although malaria parasites were found negative, clinical history of having been infected with $P$. vivax may support the incidence of anemia in the children. The recurrence of $P$. vivax infection will contribute to structural and functional changes of red blood cells, and these hematological changes cause decreased hemoglobin levels and iron deficiencies. However, from the measurement of serum iron levels, it revealed that the stunted children had lower iron levels than compared with non-stunted children (31.57 $\pm 9.88 \mu \mathrm{g} / \mathrm{dL}$ vs. $52.99 \pm 12.60 \mu \mathrm{g} / \mathrm{dL}$ ). A similar study conducted by Damayanti et al. proved that there was a significant correlation between the level of iron stores and the incidence of stunting [11].

According to Petry et al., iron deficiency in children can cause cognitive impairments and physical growth disorders [12]. Iron deficiency will inhibit neurogenesis in the hippocampus which results in morphological changes of the hippocampal neurons. The shape and size of the neurons are smaller and the number of branching neurons or synapses are reduced [13]. A study conducted by Brunette confirmed that in the mice with iron deficiency since they were intrauterine, the number of neuron branches was decreased, and the diameter of dendrite was smaller. This small diameter of dendrite decreases the speed of signal delivery [14]. Therefore, low nutrient intake, especially iron in stunted children, will give an impact on their low cognitive abilities and IQ scores which are characterized by low learning motivation and poor achievement in school [15]. The impaired cognitive development will result in the decreased performance of the nervous system which will lead to the low intelligence of children. Stunting in children can reduce their IQ scores by 5-11 points [16]. The incidence of stunting is closely related to the characteristics of parents. In this study, $60 \%$ of mothers and $54.1 \%$ of fathers with low education, and $59.9 \%$ of the families with low economic status had stunted children.

The results of this study also showed that the mean level of serum BDNF in stunted children was lower than that in non-stunted children $(3.38 \pm 1.05 \mu \mathrm{g} / \mathrm{dL}$ vs. $4.16 \pm 0.41 \mu \mathrm{g} / \mathrm{dL}$ ). BDNF is a neurotrophin that plays a role in the development of synapses, synapse plasticity, and cognitive functions and contributes to the learning process and memory functions [17]. The decrease of BDNF expression is associated with impaired neuronal differentiation in several areas of the brain. Therefore, the low levels of serum BDNF will affect cognitive functions [18].

BDNF is produced by the brain, and the brain itself is the organ containing the highest concentration of iron. Iron plays a role in the formation of myelin, dopamine, and energy in the brain. Energy formation in the hippocampus of the brain requires sufficient iron to support the learning process and memory functions. If an iron deficiency occurs, there will be a reduction in BDNF expression in the brain which will then result in behavioral and cognitive changes. The results of several studies on animal suggest that iron deficiency that occurs early in life will cause epigenetic changes that alter the structure of chromatin and expression of the BDNF genes and causes a decrease in the differentiation of neurons in the hippocampus. This is related to abnormalities of behavior and cognition, including decreased memory ability and increased anxiety. These abnormal behaviors and cognitions will persist into adulthood despite adequate treatment [18].

The results of the correlation test showed a significant correlation between the mean levels of serum BDNF and serum iron levels $(p=0.000, r=0.454)$. This proves that the impact of stunting on cognitive function is caused by the low levels of BDNF and serum iron. Iron is one of the important micronutrients needed for the development and function of brain cells. BDNF synthesis depends on the availability of iron in the brain [18]. Iron deficiency results in a reduction in BDNF expression which further impacts cognitive impairment in stunted children.

\section{Conclusion}

There was a significant correlation between BDNF mean level and serum iron levels $(p=0.000$, $r=0.454$ ) in stunted children in malaria-endemic areas. Iron is required for the synthesis of BDNF. The low level of iron serum is responsible for the low synthesis of BDNF. These problems, in the long run, surely will affect cognitive functions of stunted children. 


\section{Acknowledgment}

This research was funded by Hibah Penelitian Dasar Kemenristek Dikti Tahun 2019. Therefore, the researchers are really grateful for any assistance and support, especially from the government that enabled us to finish this project.

\section{References}

1. Harijanto P. Tata Laksana Malaria untuk Indonesia. Jakarta: Buletin, Kementrian Kesehatan RI; 2011.

2. Peraturan Presiden Nomor 131 Tahun 2015 Tentang Penetapan Daerah Tertinggal Tahun 2015-2019; 2015. https://doi. org/10.31942/jqi.v10i2.2068

3. Semba RD, Pee S, Sun K, Sari M, Akhter N, Bloem MW, et al. Effect parental formal education on risk of child stunting in Indonesia and Bangladesh: A cross sectional study. Lancet. 2008;371(9609):322-8. https://doi.org/10.1016/ s0140-6736(08)60169-5

4. Pongou R, Ezzati M, Salomon JA. Household and community socioeconomic and environmental determinants of child nutritional status in Cameroon. BMC Public Heath. 2006;6:98. https://doi.org/10.1186/1471-2458-6-98

PMid: 16618370

5. Agho, KE, Inder KJ, Bowe SJ, Jacobs J, Dibley MJ. Prevalence and risk factors for stunting and severe stunting among under-fi ves in North Maluku Province of Indonesia. BMC Pediatr. 2009;9:64. https://doi.org/10.1186/1471-2431-9-64 PMid: 19818167

6. Zere $E$, Mclntyre D. Inequities in under-five child malnutrition in South Africa. Asia Pasific J 2003;2:125-7.

7. Nokes C, Bosch C, Bundy DA. The Effects of Iron Deficiency Anemia on Mental and Motor Performance, Educational Achievement and Behavior in Children: An Annotated Bibliography. Washington, DC: Pearson; 1990.

8. Subedi L, Huang H, Pant A, Westgate PM, Bada HS, Bauer JA, et al. Plasma brain derived neurotrophic factor levels in newborn infants with neonatal abstinence syndrome. Front Pediatr.
2017;5:1-7. https://doi.org/10.3389/fped.2017.00238

9. World Health Organization. Childhood Stunting: Context, Causes and Consequences. Geneva: World Health Organization; 2010.

10. Akombi BJ, Agho KE, Hall JJ, Merom D, Astell-Burt T, Renzaho AM. Stunting and severe stunting among children under-5 years in Nigeria: A multilevel analysis. BMC Pediatr. 2017;17(1):15. https://doi.org/10.1186/s12887-016-0770-z PMid:28086835

11. Damayanti RA, Muniroh L, Farapti F. Perbedaan tingkat kecukupan zat gizi dan riwayat pemberian ASI eksklusif pada balita stunting dan non stunting. Media Gizi Indones. 2016;11(1):61-9. https://doi.org/10.20473/mgi.v11i1.61-69

12. Petry N, Olofin I, Boy E, Angel MD, Rohner F. The effect of low dose iron and zinc intake on child micronutrient status and development during the first 1000 days of life: A systematic and meta-analysis. Nutrients. 2016;8:773. https://doi.org/10.3390/ nu8120773

13. Fretham S, Carlson ES, Georgieff MK. The role of iron in learning and memory. Adv Nutr. 2011;2(2):112-21.

14. Brunette KE, Tran PV, Wobken JD, Carlson ES, Georfieff MK Gestational and neonatal iron deficiency alters apical dendrite structure of ca 1 pyramidal neurons in adult rat hippocampus. Dev Neurosci. 2010;32(3):238-48. https://doi. org/10.1159/000314341

PMid:20689287

15. Walker SP, Chang SM, Powell CA, McGregor SM. Effects of early childhood psychosocial stimulation and nutritional supplementation on cognition and education in growth stunted Jamaican children: Prospective cohort study. Lancet. 2005;366(9499):1804-7. https://doi.org/10.1016/ s0140-6736(05)67574-5

PMid: 16298218

16. World Bank. Repositioning Nutrition as Central to Development a Strategy for Large-Scale Action. Washington, DC: World Bank; 2006. https://doi.org/10.1596/978-0-8213-6399-7

17. Radlowski EC, Johnson RW. Perinatal iron deficiency and neurocognitive development. Front Hum Neurosci. 2013;7:585. https://doi.org/10.3389/fnhum.2013.00585 PMid:24065908

18. Estrada JA, Contreras I, Pliego-Rivero FB, Otero GA. Molecular mechanisms of cognitive impairment in iron deficiency: Alterations in brain-derived neurotrophic factor and insulin like growth factor expression and function in the central nervous system. Nutr Neurosci. 2014;17(5):193-206. https://doi.org/10. 1179/1476830513y.0000000084 